\title{
Money and Society
}

\author{
Rory Naismith
}

\section{Introduction}

In its most basic sense, money is a means of measuring and mediating value as understood by human society. It does not exist by nature, but by the imaginative impulse of those who need to engage in acts of exchange. For this reason diverse forms of money have taken shape throughout history across the globe (and continue to do so). ${ }^{1}$ Money, it might be said, is the creation of society, and especially of more complex societies marked by diverse interactions. But the length of and variety in this relationship mean that it has often come full circle: money has profoundly affected society, and not always in the ways one might expect. The traditional interpretation of the influence of money in modern society - which has in turn affected readings of other areas and periods - goes back to foundational figures in history and the social sciences such as Karl Marx, Georg Simmel, and Marcel Mauss, and holds that the rise of monetization in and of itself would erode more affective human bonds. ${ }^{2}$ But an important strand of recent scholarship developed by anthropologists and sociologists of the modern world has pruned back this narrative; instead, ways of incorporating money into social processes have come to the fore. ${ }^{3}$ Calculation and quantification are just one part of the story, and by no means always the dominant one, be it in the modern United States, Africa, Indonesia, or the Pacific Islands. The impact of money on any particular community depends on many more variables than the presence of money alone.

The application of this approach to medieval Europe is the central goal of this chapter. How did medieval people actually view and use money, and what impact did it have on their society (and vice versa)? This is, of course, a vast topic. Coins, ingots, and other means of exchange only became money when they factored into valuation or exchange, in relation to abstracted units of account.

1 See, for example, Maurer, "The anthropology of money", and chapter 3 in this volume.

2 Marx, Economic and Political Manuscripts of 1844, pp. 165-69; Simmel, The Philosophy of Money; and Mauss, The Gift, pp. 65 and 76.

3 Zelizer, The Social Meaning of Money; and Keane, "Market, materiality and moral metalanguage". 
Money played a central role in articulating all kinds of relationships, and in that sense was at the heart of medieval society, to the extent that the monetary aspect of human interaction risks losing all analytical value if one does not keep an equally sharp focus on the form and context of that interaction. Why did that particular individual use that particular form of money for that particular payment? And how would all parties in such a transaction have understood its significance? Close scrutiny of specific features is therefore essential, and conceiving of medieval Europe as a single society for these purposes verges on the banal: meaningful conclusions can only emerge from closer chronological, geographic, and thematic focus. The first two of these are covered to a greater degree in the chronologically specific chapters elsewhere in this volume; here, the focus is on thematic issues of money in medieval societies. Two central themes structure this chapter, which can be roughly broken down into what one may call pragmatic and symbolic segments, though in practice it will become apparent that there are important areas of overlap between them. Of necessity these approaches are schematic and selective. Pragmatic considerations revolve around how people went about using money, and how the availability of different coins or other forms of money helped or hindered that process. This includes the various settings in which money was used, in many kinds and levels of commerce as well as other exchanges (gifts, rents, taxes, etc.). Symbolic aspects cover how thought about, as well as use of, money interfaced with structuring principles of society, above all religion. In this chapter the Christian religion will be the focal point, though parallels can be drawn with Islamic and Jewish beliefs and the crossovers among their respective traditions. Related to this is the issue of money and the law: who held authority over money, and how were they to uphold that power?

Both areas have a strong tradition of scholarship behind them, driven by debates in a range of related subjects. Philosophical treatises of the later Middle Ages have prompted sharp discussion of concepts of money and its regulation; ${ }^{4}$ so too have studies on medieval Jewry. ${ }^{5}$ The scale of the question of how money interfaced with medieval Christianity means that approaches have of necessity been quite targeted. ${ }^{6}$ Much work on the actual use of money in medieval society revolves around the large-scale operation of the medieval

4 Wood, Medieval Economic Thought.

5 Johnson, "Textual sources for the study of Jewish currency crimes in thirteenth-century England"; Mundill, The King's Jews, esp. pp. 21-42; Todeschini, "The incivility of Judas"; and Mell, The Myth of the Medieval Jewish Moneylender.

6 Some degree of overview can be obtained from Le Goff, Money and the Middle Ages; see also Todeschini, "Money and religion". 
economy. Money can be viewed as a facet of the economy in several ways: as a gauge for levels of demand and wealth, including the rise and fall of rents, wages, and prices for basic commodities; ${ }^{7}$ and as a powerful factor in economic life in and of itself. ${ }^{8}$ Nicholas Mayhew discusses this dimension of money elsewhere in this volume, for which reason more attention is devoted here to the trees than the wood, and particularly to how various groups in society (including those outside the aristocratic and commercial elite, among them the peasant majority) interacted with money. Dedicated treatments of this theme are few. An elegant and succinct survey of the role money played in later medieval society is Jacques Le Goff's Money and the Middle Ages, in which he develops a persuasive view of money belonging essentially to the moral rather than the economic sphere of life. ${ }^{9}$ Peter Spufford's magisterial volume on Money and its Use in Medieval Europe remains the foundation of serious research. It is particularly outstanding for combining analysis of the different strata of money, from the highest levels of academic thought, regulation, productivity, price-setting, and bullion flow down to the experience of individuals of diverse status. ${ }^{10}$ Much of its strength derives from a grasp of the voluminous later medieval documentary and literary material relating to money (complemented by Spufford's essential handbook of medieval exchange rates). ${ }^{11}$

Since Spufford's book was written, there has been a transformation in the scale and nature of material evidence for coin-use. Finds of coins have proliferated in subsequent decades, thanks in large part to metal-detectors becoming more widely used in both amateur and professional settings. ${ }^{12}$ Laws regarding their use vary significantly between countries, ${ }^{13}$ with the result that large-scale

For a classic example, see Phelps Brown and Hopkins, A Perspective on Wages and Prices; Farmer, "Prices and wages"; Clark, "The long march of history"; and Mayhew, "Modelling medieval monetisation".

8 Bolton, Money in the Medieval English Economy 973-1489.

9 Le Goff, Money and the Middle Ages, esp. pp. 142-5o.

10 Spufford, Money and Its Use in Medieval Europe.

11 Spufford, Handbook of Medieval Exchange.

12 Dyer, "Peasants and coins"; Coupland, "Carolingian single finds and the economy of the early ninth century"; Coupland "The use of coin in the Carolingian Empire in the ninth century"; and Naismith, "The social significance of monetization in the early Middle Ages".

13 The systems which give most freedom to amateur searchers and have the largest recorded bodies of new find material are those of England and Wales (PAS) and the Netherlands (NUMIS). In Denmark, a national scheme keeps records of finds made by amateurs and encourages collaboration with archaeologists. Amateur use of metal-detectors is for the most part heavily restricted elsewhere, though detectors are now widely used by professional archaeologists. 
comparisons of find material remain problematic. It is now possible, however, to examine in detail the material traces of coin-use at individual sites (towns, rural settlements, churches, and more) in order to make qualitative comparisons between regions across Europe. ${ }^{14}$ Conclusions derived from these efforts can be placed alongside research based on documents and other texts, dovetailing effectively to show complex and integrated (if still highly variable) levels of use..$^{15} \mathrm{~A}$ whole new dimension of money in society has opened up.

\section{The Pragmatics of Money in Society}

A basic problem which confronted users of medieval money for over a millennium was how to cater for different levels of exchange in society. In modern times, it is taken for granted that everything from small change - pennies and cents so low in value that their loss is of little concern - up to quite high-value notes should be represented in plentiful and reliable form as coin or paper, with an extensive range of cheques, credit cards, and electronic transfers for handling even very large sums easily. ${ }^{16}$ Such was simply not the case in the Middle Ages. On the one hand, medieval society was monetized to its very core, in that foodstuffs, land, houses, all other commodities, human lives and bodies, and in some contexts even religious virtues and vices were rated in monetary terms. On the other, the actual mechanisms available for carrying out these transactions were often both limited and limiting. To some extent, this was accepted by medieval men and women simply as the natural state of affairs, and they found ingenious ways to adapt and work around the options open to them. But the disjuncture between the breadth of money as a structuring concept for ideas of value and the forms of money as experienced in day-to-day life is a striking feature of medieval society. ${ }^{17}$

Generally the difficulty was that the prevailing units of currency were comparatively valuable, making smaller transactions impractical. Probably the most extreme development of this was in the immediate post-Roman period.

14 See, e.g., Kelleher and Leins, "Roman, medieval and later coins from the Vintry, City of London"; Colardelle and Verdel, Les habitats du lac de Paladru (Isère) dans leur environment, pp. 284-87; and Stoess, "Die Münzen”. An important early example of this approach is Rigold, "Small change in the light of medieval site-finds".

15 The Carolingian polyptychs have been used effectively in this way: see Petry, "Das Geldzinse in Prümer Urbar von 893"; and Devroey, "Activité monétaire, marchés et politique à lâge des empereurs carolingiens".

16 Cf. chapter 3 in this volume.

17 A classic summation of this is Bloch, Feudal Society, vol. 1, pp. 66-71. 
Late Roman currency included a vast and complex base-metal coinage, which far outweighs that of the Middle Ages in quantity of modern finds. There is no doubt that it was the form of money most of the empire's populace used on a daily basis (though the volume and intensity of its circulation varied among regions, and between town and country). ${ }^{18}$ Gold and, to some extent, silver coinage of significantly higher value was also issued. In A.D. 445 butchers supplied Rome with pork at a price of one gold solidus for $200 \mathrm{lbs}(90.7 \mathrm{~kg}) \cdot{ }^{19} \mathrm{It}$ was this denomination, the solidus, and its divisions in gold which dominated state income and expenditure, and against which base-metal coins were tariffed. From the 4th century onwards the ratio of base metal to gold fluctuated widely, generally to the detriment of those in society who dealt mainly in base metal rather than gold: thus under Justinian I the value of the solidus rose from 7,200 bronze nummi in 539 to 12 , ooo by 565 . A senator of the 38 os took up the cause of money-changers who suffered from the "surging value of gold", ${ }^{20}$ and the end result was decried by the anonymous author of the 5 th-century tract De rebus bellicis, who lamented how "the private mansions of the powerful, filled from this flood of gold, were turned into more signal instruments for the oppression of the poor".21

The situation in the post-Roman western kingdoms of the $5^{\text {th }}$ century and after was better in some respects and worse in others. After the end of effective Roman rule, only gold coinage survived on any scale, preserved because of its central place in state finance. Silver and base-metal currency quickly withered. Ostrogothic Italy and Vandal Africa maintained a more substantial range of denominations, as (on a more limited scale) did the East Roman or Byzantine territories of Italy and Africa. But elsewhere in the west, by the end of the 6th century fresh coins of silver and copper alloy had effectively vanished. There was no longer even an option of low-value coin. On the other hand, the volatility which had plagued previous generations using base-metal currency was no more. Peasants may well have had less cash extracted from them, and more incentive to engage with an increasingly stable market involving coined money on a more restricted level. This would have contributed to the relative golden age of lighter exploitation experienced by the peasantry in the post-Roman centuries, ${ }^{22}$

18 De Ligt, "Demand, supply, distribution", esp. pp. 39-41.

19 Codex Theodosianus: Novellae XIII.4 (Valentinian III, 445), vol. 2, pp. 95-96. See also Jones, The Later Roman Empire, 284-602, pp. 702-3.

20 "Auri enormitas crescens". Symmachus, Relationes, 29, ed. Seeck, pp. 303-4.

21 "Ex hac auri copia privatae potentium repletae domus, in perniciem pauperum clariores effectae, tenuioribus videlicet violentia oppressis". De rebus bellicis 2.1, ed. Ireland, pp. 5 and 26 .

Wickham, Framing the Early Middle Ages, pp. 12 and esp. 519-88. 
though it must be kept in perspective: down to the 13th century (and in many areas much later), most extraction of peasant surplus had been in kind and/or labour rather than in cash. ${ }^{23}$

In the Frankish, Visigothic, and Anglo-Saxon kingdoms, coinage therefore meant gold. Currency had contracted to just the most valuable component of the late Roman system, inevitably imposing severe limits on the degree of coin-use, especially outside the elite. One concession to the high value of the coinage was that the lowest traditional denomination (the tremissis, one third of a solidus) became the preferred coin in production, even though the solidus retained primacy in terms of units of account. The quantity of gold in circulation from the late Roman period onwards also meant that its use was comparatively widespread. It could certainly be found in the hands of users well below the elite, such as Egyptian peasants of the 4th century, and some tenants in 6th-century Gaul who paid rents in gold. ${ }^{24}$ The volume of modern finds of gold pieces from the $5^{\text {th }}$ to $7^{\text {th }}$ centuries also points to its comparatively vibrant and widespread use.

Gold was, nonetheless, prohibitively valuable for a high proportion of transactions, and the fact is that inconveniently high-value denominations (by modern standards) dominated much of medieval Europe. Even the silver penny or denarius - introduced in its earliest form in England, Francia, and Frisia in the later 7 th century - had relatively substantial purchasing power. Tenthcentury laws from England set the standard compensation value for an ox at 3 od., a cow at 20 ., a pig at $10 d$. , and a sheep at 5 d., ${ }^{25}$ and the maximum prices established by Charlemagne at Frankfurt in 794 stipulated that one silver denarius should buy between 12 and 25 two-pound loaves of bread, depending on whether they were made from wheat, rye, barley, or oats. ${ }^{26}$ The early Middle Ages were particularly extreme, but throughout the period a single penny commonly had considerable buying power in terms of modern pounds, euros, or dollars, perhaps several tens in the 8th century. In England in 1473 bakers were ordered to sell three $5^{1 / 2-l b}$. loaves for one penny, ${ }^{27}$ this at a time when the daily wage for an agricultural labourer was generally less than $4 \mathrm{~d} .{ }^{28}$

23 De Ligt, "Demand, supply, distribution"; and Erdkamp, The Grain Market in the Roman Empire, pp. 101-4.

24 Banaji, Agrarian Change in Late Antiquity, pp. 39-88; Banaji, "Precious metal coinages and monetary expansion in late antiquity"; and Naismith, "Gold coinage and its use in the post-Roman West".

25 VI Æthelstan 6.2, in Liebermann, Die Gesetze der Angelsachsen, vol. 1, p. 176.

26 "Council of Frankfurt", c. 4, p. 74.

27 For this and other examples, see Davis, Medieval Market Morality, pp. 231-41. But see also chapter 7 in this volume for inconveniently low-value coins. 
For several centuries the silver penny was the only denomination minted on any scale in western Europe. Its spread and adoption in northern and eastern lands, along with the system of account associated with it, was one manifestation of the extension of mainstream European cultural norms in the 11th to 13th centuries. ${ }^{29}$ Manipulation of the penny - the cornerstone of monetary life - frequently proved profoundly disruptive. On 1o March 1223, memories of a monetary turning point formed the crux of a legal case heard in Umbria, in which a tenant of the monastery of Sassovivo questioned whether the annual render from a property leased some 70 years earlier had been stipulated in Pavian or Luccan coin (the latter being significantly less valuable). Witnesses described how the Luccan currency had gained prominence in the area only after the transaction, when Emperor Frederick Barbarossa (1155-1190) had "ruined" (devastavit) the Pavian coinage. ${ }^{30}$ This change had left a very real and memorable impression, and problems arising from such situations exercised the minds of medieval jurists. ${ }^{31}$ The exact outcome of currency manipulation was highly variable. Strengthening it (i.e. increasing its fineness) raised the real value of fixed payments such as rents and tolls, while debasement, as at Pavia under Frederick, had the opposite effect, and could serve, deliberately or otherwise, to reduce the value of individual coins and make the currency more versatile. ${ }^{32}$ Some of these consequences could also emerge from inflation generated by other pressures, as happened in England in the decades around 1200 when a combination of forces led to a jump in prices despite a relatively pure currency. ${ }^{33}$ In general, however, changes to the central monetary denomination affected prices, which in turn destabilized society as a whole.

For peasants, dealing with the monetary economy was by no means a common, welcome, or easy undertaking, but all segments of medieval society had to deal with fundamental practical problems posed by their currency. Not only were few low-value coins available, but between the end of widespread gold currency in the 7th and 8th centuries and the appearance of new large silver and gold denominations in the $13^{\text {th }}$ and 14 th, ${ }^{34}$ there was also little cash available to facilitate high-value transactions. Members of the elite had

29 Bartlett, The Making of Europe, pp. 280-87.

$30 \quad$ Le carte dell'Abbazia di S. Croce di Sassovivo, vol. 6, pp. 34-38 (no. 21).

31 Ernst, "The legists' doctrines on money and the law from the eleventh to the fifteenth centuries".

32 Cipolla, "Currency depreciation in medieval Europe"; and Morrisson, "La devaluation de la monnaie byzantine au XIe siècle".

33 Harvey, "The English inflation of 1180-1220", pp. 16-24; Latimer, "The English inflation of 1180-1220 reconsidered"; and Bolton, Money, pp. 176-87. See also chapter 9 in this volume. 
several other options besides vast quantities of silver coin. Foreign gold pieces were sometimes pressed into use, such as the mancosi of 8th- and 9th-century Italy ${ }^{35}$ or the bezants (Byzantine gold coins) and Muslim gold pieces of the 11th to 13 th centuries. ${ }^{36}$ Precious metal objects also served to store and convey large amounts, as when Otbert, bishop of Liège (1091-1119), had to raise the vast sum of at least 1300 silver marks (and three in gold) as a loan for the duchy of the departing crusader Godfrey of Bouillon. Doing so involved ransacking the gold and silver reserves of churches in the diocese. ${ }^{37}$ Ingots were used from time to time, especially in the later 12 th century and after. ${ }^{38}$ Bills of exchange emerged as a mechanism for substantial sums to be transferred remotely, initially (in the later 12th century) among merchants but quickly coming to be used much more widely. ${ }^{39}$ Reducing the need to move large quantities of gold or silver also served to encourage investment of cash instead of hoarding. ${ }^{40}$

Bills of exchange emerged and prospered in contexts where the existing money supply was especially rich and dynamic. The decision to engage in direct commodity exchange, or to use precious metal objects or goods instead of cash, was driven in some times and places by the sheer scarcity of coined money, not the lack of a large denomination. The medieval money supply had to work much harder than that of many modern economies, in that coins changed hands significantly more often. ${ }^{41}$ Hence it sometimes happened that money simply was not available when it was needed. Even a 15th-century East Anglian gentleman had to wait overnight in Norwich in the hope of receiving payment in cash from a debtor who in turn awaited payment. ${ }^{42}$ Small change in particular was often in short supply, if it existed at all. It cost as much time and labour to produce a halfpenny or farthing as a higher-value coin such as a

35 The origin of these has recently been the subject of renewed debate: Prigent, "Le mythe du mancus et les origines de l'économie européenne"; Delogu, "Il mancus è ancora un mito?"; and Cosentino, "Ricchezza e investimento della Chiesa di Ravenna tra la tarde antichità e l'alto medioevo", pp. 431-39.

36 E.g. Cook, "The bezant in Angevin England"; and Carpenter, "Gold and gold coins in England in the mid-thirteenth century".

37 The several sources discussing Otbert's fundraising are listed and discussed in Murray, "Money and logistics in the forces of the First Crusade", pp. 239-40. Some, but not all of this amount was probably minted into coin.

38 Spufford, Money, pp. 209-24. For the much more extensive use of bullion in monetary contexts among the Vikings, see chapter 5 .

39 Spufford, Money, pp. 254-59; and Spufford, Power and Profit, pp. 34-38.

40 Spufford, Money, pp. 259-62.

41 Mayhew, "Modelling", pp. 68-71.

42 Mayhew, "The monetary background to the Yorkist Recoinage of 1464-1471", pp. 69-72. Cf. Paston Letters and Papers of the Fifteenth Century, vol. 1, p. 593. 
penny, and so making small coins was unpopular among those charged with responsibility for minting. ${ }^{43}$ Flooding the market with low-value coins could create quite different problems, leading to inflation of good silver and gold and even refusal of low-value pieces, as happened in Scotland around $1480 .{ }^{44}$ Yet small change was popular and desirable, and served a distinct purpose. One female buried in the East Smithfield plague cemetery in London, which contained victims of the Black Death in the mid-14th century, had a purse of lowvalue coin at her belt for easy access and a concealed cache of higher-value pieces in her armpit. 45 "Black money", referring to the lowest-value coins of highly debased silver in later medieval Europe, was the backbone of monetary exchange for poorer members of society. ${ }^{46}$ In the early Middle Ages, halfpennies were made on a limited scale. An anecdote in the gth-century miracles of St Philibert revolved around the rarity of oboli or halfpennies. ${ }^{47}$ In 10th- to 13thcentury England, halfpennies and farthings made by cutting full coins into halves or quarters occur with considerable frequency on some archaeological sites, suggesting that these makeshift low-value pieces enjoyed considerable popularity. ${ }^{48}$ After the first appearance of a limited range of (relatively) small change in the late 13th century, the English parliament was beset many times with complaints that smaller denominations were too scarce and the currency in general too dear. ${ }^{49}$

A simple way of managing the limitations of the monetary system was to vary a commodity's quantity (by weight or volume) in relation to a standard monetary value, rather than expect users to find variable and unwieldy sums to buy a fixed quantity. Charles the Good, count of Flanders (1119-1127), was said to have decreed in a time of famine that the regular penny-sized loaves should be halved so that people with only an obol to offer would still have the means to buy food. ${ }^{50}$ In times of both need and plenty, there was much regulation of the weight of a loaf of bread worth a given small sum. Other techniques for dealing with a high-value currency might have included bulk purchases or extensive use of personal credit or lower-value commodities. Some of these mechanisms are discussed in detail elsewhere in this volume in the

43 Sargent and Velde, The Big Problem of Small Change.

44 Gemmill and Mayhew, Changing Values in Medieval Scotland, pp. 125-28.

45 Sloane, The Black Death in London, pp. 98-99.

46 Munro, "Deflation and the petty coinage problem in the late-medieval economy"; and Spufford, Money, pp. 329-31.

47 See discussion below.

48 Kelleher and Leins, "Roman", p. 18 o.

49 Desan, Making Money, pp. 104-7.

50 Walter of Thérouanne, Vita Caroli comitis Flandriae, p. 38. 
chapters by Bill Maurer and Gaspar Feliu. However, for much of the population the problem would have been tempered by their only having to use money infrequently - well below 50 per cent of all transactions would have involved coin before the 13th century, and been heavily concentrated in the most highly urbanized and monetized areas of Italy and northern Europe. ${ }^{51}$

Agricultural or pastoral production occupied the bulk of the population throughout medieval Europe, and those who lived on the land would have been able to produce at least some of their own food and help make up any shortfall by bargaining with friends and family. Nonetheless, it is unlikely that many (if any) peasants were entirely self-sufficient, and a cocktail of money rent, sale of surplus, cash crops, and wage labour all served to foster use of money in the countryside. The balance and effect of these processes depended heavily on local conditions. Areas with a dispersed and less integrated population tended to see less cash filter into society. Directions of bullion flow were also a factor, along with the presence of wealthier landowners who provided a powerful centripetal force, especially in more marginal cases. ${ }^{52}$ These challenges were already being faced very early in the Middle Ages: Carolingian peasants taking crops to market and returning with a few coins (often to pay rent) was a common topos of 9 th-century miracle stories, ${ }^{53}$ and the bawdy 1 th-century fable Unibos is replete with money-grubbing peasants wheeling and dealing in cash. ${ }^{54}$ Monetization of the countryside was thus by no means a new phenomenon in the later 12th and 13th centuries, although the availability and impact of money (not least through quickening inflation) stepped up markedly.

The encroachment of cash brought mixed blessings for the rural population. For those engaged in agricultural toil, dealing in money offered a higher degree of flexibility in use of resources - above all the option of more and better food and less time working, but also consumer goods or even land purchases - as well as the capacity to do business with a wider range of partners. ${ }^{55}$ Money also created new uncertainties. Fixed money rents were prone to lose real value as a result of inflation; as a result landlords sometimes had to find alternative forms of income and tenants on the whole stood to benefit, although there was as much variation in the experience of peasants as in their level of material wealth. ${ }^{56}$ In late 12th- and 13th-century Picardy, for example, rising availability

$5^{1}$ Cf. the figures cited in Naismith, Money and Power, pp. 285-86.

52 Wickham, "Rethinking the structure of the early medieval economy"; and Naismith, "Social significance", pp. 30-37.

53 Naismith, Money and Power, pp. 28o-82; and Coupland, "Use of coin", pp. 257-59.

54 Versus de Uniboue.

55 Hatcher, “Unreal wages", p. 21.

56 Spufford, Money, pp. 243-44. 
of money led to monetization of rents on peasant holdings. ${ }^{57}$ Richer peasants with substantial produce benefited, as their income significantly exceeded the rent demanded from them, whereas their poorer counterparts who could not sell enough of their own produce to raise the rent had to undertake additional paid labour (which came in irregular fits and starts in pre-modern agrarian societies).$^{58}$ Whatever they did sell was food which they did not have to eat, and tended to come onto the market at times of plenty when prices were low.

Increased use of money thus conspired in several ways to leave poorer peasants in a precarious situation. Wealthier members of society were capable of manipulating the rhythms of the agricultural economy to their advantage when crops were placed on the market. Large-scale landowners, such as aristocratic households or monasteries, represented significant consumers as well as producers, and would be able to force low prices onto numerous small producers at harvest, as well as charge exorbitant sums for their surpluses in times of need. This practice was directly challenged at the council of Paris in $829 .{ }^{59}$ Lords could also adjust the form of their income to strengthen their own ability to profit from growing urban markets. In both England and Tuscany, the 13th and 14th centuries saw a relative resurgence in labour services and renders in kind. This has been interpreted as an attempt to generate more produce for sale to urban buyers - and to detract from tenants' capacity to sell directly to those same buyers. ${ }^{60}$ Money hence made the rural economy more malleable, but opened up new avenues to subtle exploitation.

\section{Thinking about the Symbolism of Money: Law and Religion}

As noted above, money was everywhere in medieval society even if coins came and went. Law-codes promulgated in the post-Roman kingdoms of western Europe rated legions of infractions in monetary terms, including damage to body parts down to individual toenails and fingernails. ${ }^{61}$ Payments in res valentes "goods to the equivalent value" - were still thought of in terms of standardized denominations in gold and silver. ${ }^{62}$ The most prevalent system was that of

57 Fossier, La terre et les hommes en Picardie jusqu’à la fin du XIIIe siècle.

$5^{8}$ Hatcher, “Unreal wages", pp. 8-10.

59 "Council of Paris", pp. 645-46.

6o Spufford, Money, pp. 243-45; Wickham, The Mountains and the City, p. 229; and Kotel'nikova, "Rendita in natura e rendita in denaro nell'Italia medievale (secoli IX-XV)".

61 Miller, Eye for an Eye; and Oliver, The Body Legal in Barbarian Law.

62 See chapter 2 in this volume. 
pounds, shillings, and pence, which originated in early medieval Francia and survived in one form or another until the 1970s. Many other methods of rating value were also tied notionally to quantities of precious metal, some of which were represented by coins. Others looked to different standards of value: early medieval Irish laws used slaves and cattle rated by age and gender, ${ }^{63}$ while standardized lengths of fabric fulfilled this role in later medieval Iceland. ${ }^{64}$ In all areas, the relationships of different coins, metals, commodities, and units of account could be positively mind-boggling. The advent of gold and more diverse silver denominations in the $13^{\text {th }}$ century enabled coined money to play a larger role, though the variety and instability of currency still posed an ongoing challenge. ${ }^{65}$ The central point is that thought in terms of money was ubiquitous, and had been since before the beginning of the Middle Ages.

As a fundamental principle in society, money factored into larger concepts of organization in a range of ways. It was closely associated with notions of structure and order. Each individual had his or her own monetary price, varied by class and gender, to be paid as compensation to the family by the killer in case of death. ${ }^{66}$ Cassiodorus (d. c.585) drew a comparison between the number of denarii in a solidus and the number of years in the age of the world. ${ }^{67} \mathrm{In}$ his laws and other writings from late Anglo-Saxon England, Archbishop Wulf$\operatorname{stan}(\mathrm{d} .1023)$ associated proper regulation of coinage with morality and stability in a God-fearing kingdom. ${ }^{68}$ More pragmatically, large-scale reorganization of money often went hand in hand with adjustments to systems of weights and measures, as in Charlemagne's strictures laid down at the council of Frankfurt in $794 .{ }^{69}$ The treatment of money in legal texts from across the Middle Ages underscored its integral role in society, and the interest rulers had in its regulation. Although some texts were focused solely on money, they commonly treated it alongside urban and trading customs, giving an important clue to what associations money had. Numerous charters of the Ottonian and Salian

63 Breatnach, "Forms of payment in the early Irish law tracts", shows how these did not always correspond to actual slaves or cattle-and in some cases could even be applied to gold or silver.

64 Byock, Medieval Iceland, pp. 79-8o.

65 A point well formulated in Bloch, "Économie-nature ou économie-argent", p. 14.

66 See n. 61.

67 Cassiodorus, Cassiodori senatoris Variae I.10, p. 19.

68 V Æthelred, c. 26.1, VI Æthelred, c. 31 and 32.1-2, and II Cnut, c. 8, in Liebermann, Gesetze, vol. 1, pp. 242-43, 254-55 and 314-15.

69 "Council of Frankfurt", cc. 4-5, p. 74. See more broadly Ernst, "Mensura et mensuratum". 
eras granted local rulers in the Reich rights over markets, tolls, and minting in a given location..$^{70}$

A central concern raised in these charters and other documents was who should profit from the coinage and by how much. A detailed set of agreements from mid-11th-century Barcelona records the payment (in grain) and other conditions expected from successive mintmasters to whom the count farmed out coining operations. ${ }^{71}$ These texts carefully spelt out that the moneyers were to maintain the standards of the coinage as established by customary usage. In the 12th century, a new form of legal stipulation emerged in parts of what is now France and northern Spain, in which rulers pledged to maintain the coinage at its traditional standard in return for a levy on other goods to offset the profit he or she would have made by debasing it. In one early example from Catalonia issued in 1118, the stability of the coinage was just one element of a more general peace which the payment was raised to secure; later, the tax was tied more specifically to the coinage. ${ }^{72}$ But probably the most abiding concern related to the monetary system that emerged in legal discourse was that of standards and their preservation. Any infringement of the integrity of the coinage - including clipping and similar crimes as well as forgery - was tantamount to undermining the ruler's own authority, and carried appropriately heavy penalties. In 1oth-century England, King Æthelstan (924/925-939) stipulated that a moneyer caught issuing defective coin would lose a hand and it would be erected over the mint building. ${ }^{73}$ Key English legal compilations of the 12th and 13th centuries (including Glanvill and Bracton) built on the AngloSaxon foundations to include forgery among crimes of lèse-majesté which incurred capital or similarly severe punishments. ${ }^{74}$ How often these commands were actually enacted is unclear, but in 1125 Henry I (110o-35) had a large number of moneyers mutilated for (allegedly) producing debased coin. ${ }^{75}$

This bond between money and legal authority held fast across the Middle Ages: rule of law underpinned the use of money, especially as the reach of the

$70 \quad$ Kluge, Deutsche Münzgeschichte von der späten Karolingerzeit bis zum Ende der Salier (ca. goo bis 1125), pp. 101-4.

71 Botet y Sisó (ed.), Les monedes catalanes, vol. 1, pp. 200-2. Cf. Els pergamins de l'Arxiu Comtal de Barcelona de Ramon Borrell a Ramon Berenguer I, vol. 3, nos. 468, 520, and 678 .

72 This phenomenon is studied in detail in Bisson, Conservation of Coinage. For the 1118 text, see Balaguer, Història, pp. 342-43 and docs. 72-3.

73 II Æthelstan c. 14.1, in Liebermann, Gesetze, vol. 1, pp. 158-59.

74 Desan, Making Money, pp. 87-89.

75 The purge (which involved loss of testicles as well as hands) was widely reported in contemporary annals and histories: see Allen, Mints and Money in Medieval England, pp. $27-29$. 
latter extended and the range of denominations and instruments expanded. ${ }^{76}$ Enforcing payments and respect for currency in a time of fast-paced change was a challenge both to users and legislators, with the interests of the two sometimes clashing sharply. England in the late 13th century was faced with a dangerous monetary situation, in which imitations of native money (the so-called "crockards" and "pollards" issued in the Low Countries) circulated extensively and threatened to drive the better-quality English pennies out of use. The king, Edward I (1272-1307), and his agents responded around 1300 by fixing prices for basic commodities with the assizes of bread, ale, and wine, at the same time decreeing that the foreign imitations would be accepted at half the value of equivalent sterling pennies. In principle, this policy should have been beneficial to holders of foreign coin, as their intrinsic value was greater than a halfpenny, so having them reminted would have both injected silver into the domestic currency and provided a profit for individual owners. Many people, however, resisted the revaluation, believing that crockards and pollards would soon be demonetized altogether and not wanting to be lumbered with unspendable coin. Hence, the king's courts filled up with tradesmen who had rejected foreign coin or hiked their prices when faced with them. Others came to court over another royal provision - that debts incurred before the adjustment in value of crockards and pollards had to be paid at the face value of current money, which served to antagonize creditors who received imitations in settlement (albeit at appropriate value) and also debtors who sometimes found the same amount of money coming out at a lower value because of its imitative content. ${ }^{77}$ During this challenging period, administrative decisions aimed at restoring the stability and status of the English currency, implemented through legal enactments, conflicted with the wariness of society as a whole. The basic aims of law and the needs of society were not always identical, and money (integral to both) was a potential flashpoint.

There was also a law beyond the law which governed the role of money in medieval society. Christian religion exerted a powerful influence on how money was conceived of and used, not least through influencing the outlook of lawmakers, as mentioned above. But the effects of religious thought on money ran much deeper. From the later years of the Roman Empire onwards, Christian iconography became commonplace on coinage, and was ubiquitous in the Middle Ages. ${ }^{78}$ Placement of a cross, saint, religious invocation, or similar on

\footnotetext{
76 See also chapter 1 , this volume.

77 Desan, Making Money, pp. 141-49. See also Mate, "Monetary policies in England, 12721307"; and Prestwich, "Edward I's monetary policies and their consequences".

78 For a case study, see chapter 12, this volume.
} 
coined money invoked a universal element of social identity, and might carry strong local resonance; it also made crimes against the currency into crimes against God as well as the secular authorities. ${ }^{79}$

The use of money interfaced with medieval Christianity in a number of ways. Coinage was recognized as a foundational mechanism in the running of society, including on the part of the Church. Tithes and other dues were commonly expected in cash, as were pious gifts and a host of other ecclesiastical payments. One tranche of largely English silver coins was found in the Roman Forum, with a pair of fasteners identifying the hoard as a gift for Pope Marinus II (942-946). ${ }^{80}$ No stigma was attached to expressions of devotion in money, at least on the part of laymen: fears of simony (i.e., exchanging the cure of souls for money), especially during and after the papal reform movement of the 11th century, introduced more caution about the influence of money on clergy. ${ }^{81}$ Miracle collections include numerous stories of how those who stole money from a church or withheld a promised donation suffered divine retribution. ${ }^{82} \mathrm{~A}$ dramatic story in the Miracula sancti Benedicti of the 11th century illustrates very effectively how money was incorporated into divinely governed society. A servile peasant named Stabilis fled from his master, the monastery of St Benedict at Fleury, and stopped paying the census due to the church. Later, a monk from Fleury happened to spot Stabilis at the new home where he had set himself up in Burgundy. The monk tried to reclaim St Benedict's rightful property, but Stabilis resisted, and the dispute was eventually put to a trial by combat. Stabilis had not expected the case to proceed so far, and at the beginning of the fight he took a halfpenny (obolum) out of his sleeve and threw it on the ground as a "proof of his servitude" (servilis testimonii). Miraculously, the coin instantly grew to be as big as a shield, defending Benedict's property, signalling the saint's victory in the case and forcing the unfortunate Stabilis back to his lowly roots. ${ }^{83}$ Religion and money could thus work hand in hand to reinforce the integrity of society. Correspondingly, rejection of money sometimes meant the rejection of other social norms, including property and mainstream Christianity itself. Orthodox commentators on 11th-century heretics noted how the latter rejected conventional norms of money and property. ${ }^{84}$

79 Naismith, Money and Power, pp. 47-86.

8o Naismith and Tinti, The Forum Hoard of Anglo-Saxon Coins; also Naismith, "The Forum hoard and beyond".

81 Reuter, "Gifts and simony".

82 Naismith, "Turpe lucrum?", p. 31.

83 Andrew of Fleury et al., Miracula sancti Benedicti, vi.2, pp. 218-21.

84 Naismith, “Turpe lucrum?", p. 36. 
Money was also used to target the Jews. Christians as well as Jews were accused of numerous currency crimes in 13th-century England - but although the former were more numerous, Jews were ten times more likely to the suffer the death penalty, and much less often able to get away with a fine..$^{85}$

Perhaps the most eloquent instance of the integration of money into Christian belief and society came with the legend of the 30 pieces of silver: a series of texts which recounted how the batch of coins paid to Judas to betray Christ had passed from one biblical figure to another for centuries, featuring in many of the most prominent monetary gifts or payments of the Old Testament. ${ }^{86}$ The earliest incarnation of the legend, in the Pantheon of Godfrey of Viterbo (d. c.1196), claimed to be based on an (apocryphal) account by St Bartholomew which may have had an Armenian provenance. ${ }^{87}$ According to Godfrey's version of events, the coins began life as the gold furnished to Ninus, Assyrian founder of Nineveh, by Terah, father of Abraham. They were subsequently used by Abraham to buy Sarah's burial plot and for the purchase of Joseph as a slave, and ended up in the temple of Solomon before being looted by Nebuchadnezzar. He in turn gave the gold to three wise men who brought it to the new-born Christ as one of their three gifts. After a sojourn in Armenia, the gold was placed in the temple before finally being given to Judas. In this way, the to and fro of monetary exchange itself became the stuff of miraculous legend. Godfrey was aware of the rather dubious historical leaps of faith this tale required, not least from gold to silver, and sought to circumvent the apparent discrepancy by claiming that ancient usage interchanged the names for gold and silver freely. The appearance and popularization of this legend in later medieval Europe doubtless owes much to the increasing monetization of the period. Indeed, ancient coins were sometimes identified as relics of the 30 pieces of silver handed over to Judas, and enshrined as such; one, now in the Hunt Museum, Limerick, is a Syracusan dekadrachm of c.40o B.C. contained within an early 14th-century mount inscribed QVIA PRECIVM SANGVINIS EST ("since it is the price of blood"). ${ }^{88}$ Others, some surviving, some known only from illustrations, included Celtic coins and, most commonly, silver pieces from ancient Rhodes, which featured a vaguely Christ-like bust. ${ }^{89}$

85 Rokeah, "Money and the hangman in late-13th-century England".

86 Studies of the legend include Hill, "The thirty pieces of silver"; Hook, "The legend of the thirty pieces of silver"; Cherchi, "A legend from St Bartholomew's gospel in the twelfth century"; and Cherchi, "Juan Manuel's Libro de los estados (2:6-32) and Godfrey of Viterbo's Pantheon (books 13-14)".

87 Godfrey of Viterbo, Pantheon sive Universitatis Libri, qui Chronici appelantur, $X X$, vol. 14, col. 406-7.

88 Cherry and Johnston, "The Hunt dekadrachm".

89 Hill, "Thirty", pp. 245-54. 
Not only was money deeply integrated into medieval Christian belief, but Christianity was embedded into monetary forms of exchange. Rooted in the highly commercialized and monetized world of ist-century Judea, Christianity had always been heavily permeated by the language of the marketplace. ${ }^{90}$ The result was that aspects of economic life were governed, at least in principle, by the moral and social ideals advocated in the Bible. A great many miracle stories revolve around money and its proper use and provide vivid incidental insight into how writers saw money functioning around them. One gthcentury text from western France reported how a poor man (one of the plebeia multitudo who gathered at the shrine of St Philibert) went to a nearby tavern to buy some wine. He wanted an obol's (halfpenny) worth, but had only a full denarius (penny) with which to pay. The barman gave him an obol in change, but inadvertently also a full penny's worth of wine. When the customer came back and brought his coin to the barman for another round, he was met with the words, "You must be having a laugh, mate: what you've got there is mine, not yours, as you took away both my wine and my money".91 According to the story, the customer angrily denied the charge and swore (falsely) on St Philibert that he would vomit up the wine he had just drunk if the accusation were true. The saint did not take kindly to this, and inflicted prompt and messy vengeance. The drinker then sheepishly handed over the coin and slunk away. ${ }^{92}$ This memorable anecdote, suggestive of how peasants and shopkeepers used coined money on a daily basis and dealt with concomitant problems of making small change, also served to reinforce the importance of swearing truthfully and not swindling one's fellows. A similarly exemplary miracle story included in a letter of Peter Damian (d. 1072/1073) told of how a couple on pilgrimage to Rome lost a purse of money in Lake Bolsena. They persevered despite this hardship. On the way home, they stopped at the same lake for a meal. Importantly, when the husband asked to buy a fish from a fisherman, he calmly agreed to pay the higher price of 15 pence instead of the 12 he first offered. The couple then found their missing purse in the stomach of the fish, God having recognized their frugal and fair conduct and seen fit to repay them in kind.${ }^{93}$ Money, as a tool of exploitation, needed to be handled with care, and was supposedly under the ever-watchful eye of God.

90 Naismith, "Forum hoard", pp. 49-51; Brown, The Ransom of the Soul, pp. 20-33; and Brown, "From patriae amator to amator pauperum and back again".

91 "Bene ... tibi jocaris, amice; non enim tuum sed meum affers. Tulisti quippe meum et vinum et pretium".

92 Ermentarius, De translationibus et miraculis sancti Filiberti, I.71, in Monuments de l'histoire des abbayes de Saint-Philibert, pp. 49-50. 


\section{Conclusion}

If there is a single message to emerge from the role of money in medieval society, it is one of adaptability and integration in the face of practical obstacles. Money can be studied as an isolated phenomenon, but it gains immeasurably in analytical strength when viewed as part of a larger whole, with near limitless perspectives on offer to the scholar. It responded to, but also influenced other developments, particularly those associated in the broadest sense with economic life, from the hard choices of individual peasants up to the policy decisions of kings and princes.

Although the tendency is to assign to money what amounts to a sort of agency, the reality is that whatever effect money has is generated by innumerable individual human acts. As a collective these serve to distance money from its actual interpersonal role, just as Marx famously realized when he highlighted its alienating quality in relation to labour. But within these countless individual acts is a strong thread of flexibility dependent on cultural conditions. Necessary for integration into different spheres of life, money had to be versatile and capable of being transferred between people and situations. The terms on which it did so were, at least in the context of western Europe since Roman times, arguably at their most straitened and marginal in the Middle Ages. Much of the interest in studying money at this time lies in how, despite its often small and in some respects marginal economic role, it continued to occupy a central place in many aspects of thought and society.

\section{Bibliography}

\section{Primary Sources}

Andrew of Fleury et al., Miracula sancti Benedicti / Les miracles de Saint Benoit, E. de Certain (ed.), Paris, 1858.

Le carte dell'Abbazia di S. Croce di Sassovivo, 7 vols., L.S. Olschki (ed.), Florence, 19731983.

Cassiodorus, Cassiodori senatoris Variae (Monumenta Germaniae Historica: Auctores Antiquissimi, 12), T. Mommsen (ed.), Berlin, 1894.

Codex Theodosianus: Theodosiani libri XVI: cum constitutionibus Sirmondianis et leges novella ad Theodosianum pertinentes, 2 vols., T. Mommsen and P.M. Meyer (eds.), Berlin, 1905 .

"Council of Frankfurt" (794), in Capitularia regum Francorum (Monumenta Germaniae Historica: Capitularia regum Francorum, 1), A. Boretius (ed.), Hanover, 1883, 73-78. 
"Council of Paris" (829), in Concilia aevi karolini 1.2 (Monumenta Germaniae Historica: Concilia, Vol. 2, Part 2), A. Werminghoff (ed.), Hanover, 1908, 6o5-8o.

De rebus bellicis, R. Ireland (ed.), Oxford, 1979.

"Ex miraculis S. Filiberti auctore Ermentario" (Monumenta Germaniae Historica: Scriptores, 15, 1), O. Holder-Egger (ed.), Hanover, 1887, 297-303.

Godfrey of Viterbo, Pantheon sive Universitatis Libri, qui Chronici appelantur, XX, J. Herold (ed.), Basel, 1559 .

Liebermann, F. (ed.), Die Gesetze der Angelsachsen, 3 vols., Halle, 1903-1916.

Monuments de l'histoire des abbayes de Saint-Philibert, A. Giry, Ermentarius, R. Poupardin (eds.), Paris, 1905 .

Paston Letters and Papers of the Fifteenth Century, 2 vols., N. Davis (ed.), Oxford, 19711976.

Els pergamins de l'Arxiu Comtal de Barcelona de Ramon Borrell a Ramon Berenguer I, 3 vols., G. Feliu and J.M. Salrach (eds.), Barcelona, 1999.

Damian, Peter. Epistolae, as Die Briefe des Petrus Damiani, 4 vols. (Monumenta Germaniae Historica: Die Briefe der deutschen Kaiserzeit 4.1-4), K. Reindel (ed.), Munich, 1983-1993.

Symmachus, Relationes, as Q. Aurelii Symmachi quae supersunt (Monumenta Germaniae Historica: Auct. Ant. 6.1), O. Seeck (ed.), Berlin, 1883.

Versus de Uniboue, as T.A.-P. Klein (ed.), "Versus de Uniboue: Neuedition mit kritischen Kommentar," Studi Medievali, 3rd ser., 22 (1991), 843-86.

Walter of Thérouanne, Vita Karoli comitis Flandrie, J. Rider (ed.), Turnhout, 2006.

\section{Secondary Literature}

Allen, M., Mints and Money in Medieval England, Cambridge, 2012.

Balaguer, A.M., Història de la moneda dels comtats catalans, Barcelona, 1999.

Banaji, J., Agrarian Change in Late Antiquity: Gold, Labour, and Aristocratic Dominance, 2nd ed., Oxford, 2007.

Banaji, J., "Precious metal coinages and monetary expansion in late antiquity", in F. De Romanis and S. Sorda (eds.), Dal Denarius al Dinar: l'Oriente e la moneta romana: atti dell'incontro di studio, Roma 16-18 settembre 2004, Rome, 2006, 265-303.

Bartlett, R., The Making of Europe: Conquest, Colonization and Cultural Change 9501350, London, 1993.

Bisson, T.N., Conservation of Coinage: Monetary Exploitation and its Restraint in France, Catalonia and Aragon (c.A.D. 1000-c.1225), Oxford, 1979.

Bloch, M., "Économie-nature ou économie-argent: un pseudo-dilemme", Annales d'histoire sociale 1 (1939), 7-16.

Bloch, M., Feudal Society, 2 vols., London, 1961.

Bolton, J.L. Money in the Medieval English Economy 973-1489, Manchester, 2012.

Botet y Sisó, J. (ed.), Les monedes catalanes, 3 vols., Barcelona, 1908-1911. 
Breatnach, L., "Forms of payment in the early Irish law tracts", Cambrian Medieval Celtic Studies 68 (2014), 1-20.

Brown, P., "From patriae amator to amator pauperum and back again: social imagination and social change in the West between Late Antiquity and the early Middle Ages, ca. 300-6oo", in D.T. Rodgers, B. Raman, and H. Reimitz (eds.), Cultures in Motion, Princeton, 2013, 87-106.

Brown, P., The Ransom of the Soul: Afterlife and Wealth in Early Western Christianity, Cambridge, MA, 2015 .

Byock, J., Medieval Iceland: Society, Sagas, and Power, Berkeley, 1988.

Carpenter, D., "Gold and gold coins in England in the mid-thirteenth century", Numismatic Chronicle 147 (1987), 106-13.

Cherchi, P., "Juan Manuel's Libro de los estados (2:6-32) and Godfrey of Viterbo's Pantheon (books 13-14)", Romance Philology 38 (1984-1985), 300-9.

Cherchi, P., "A legend from St Bartholomew's gospel in the twelfth century", Revue biblique 91 (1984), 212-18.

Cherry, J., and Johnston, A., "The Hunt dekadrachm”, Antiquaries Journal 95 (2015), 1-6.

Cipolla, C.M., "Currency depreciation in medieval Europe", Economic History Review, 2nd ser., 15 (1963), 413-22.

Clark, G., "The long march of history: farm wages, population, and economic growth. England 1209-1869", Economic History Review 6o (2007), 97-135.

Colardelle, M., and Verdel, E., Les habitats du lac de Paladru (Isère) dans leur environnement: la formation d'un terroir au XIe siècle, Paris, 1993.

Cook, B.J., "The bezant in Angevin England", Numismatic Chronicle 159 (1999), 255-75.

Cosentino, S., "Ricchezza e investimento della Chiesa di Ravenna tra la tarde antichità e l'alto medioevo", in S. Gelichi and R. Hodges (eds.), From One Sea to Another: Trading Places in the European and Mediterranean Early Middle Ages: Proceedings of the International Conference, Comacchio 27th-29th March 20o9, Turnhout, 2012, 417-39.

Coupland, S., "Carolingian single finds and the economy of the early ninth century", Numismatic Chronicle 170 (2010), 287-319.

Coupland, S., "The use of coin in the Carolingian Empire in the ninth century", in R. Naismith, M. Allen, and E. Screen (eds.), Early Medieval Monetary History: Studies in Memory of Mark Blackburn, Farnham, 2014, 257-93.

Davis, J., Medieval Market Morality: Life, Law and Ethics in the English Marketplace, 1200-1500, Cambridge, 2012.

Delogu, P., “Il mancus è ancora un mito?", in S. Gasparri (ed.), 774: ipotesi su una transizione, atti del Seminario di Poggibonsi, 16-18 febbraio 2006, Turnhout, 2008, 141-6o.

Desan, C., Making Money: Coin, Currency, and the Coming of Capitalism, Oxford, 2014.

Devroey, J.-P., "Activité monétaire, marchés et politique à l'âge des empereurs carolingiens", Revue belge de numismatique et de sigillographie 161 (2015), 177-232. 
Devroey, J.-P., "Units of measurement in the early medieval economy: the example of Carolingian food rations", French History 1 (1987), 68-92.

Dyer, C., "Peasants and coins: the uses of money in the Middle Ages", British Numismatic Journal 67 (1997), 30-47.

Erdkamp, P., The Grain Market in the Roman Empire: A Social, Political and Economic Study, Cambridge, 2005.

Ernst, W., "The legists' doctrines on money and the law from the eleventh to the fifteenth centuries", in D. Fox and W. Ernst (eds.), Money in the Western Legal Tradition: Middle Ages to Bretton Woods, Oxford, 2016, 110-35.

Ernst, W., "Mensura et mensuratum: money as measure and measure for money", in J. von Hägen and M. Welker (eds.), Money as God? The Monetization of the Market and its Impact on Religion, Politics, Law, and Ethics, Cambridge, 2014, 6o-79.

Farmer, D., "Prices and wages", in H. Hallam (ed.), The Agrarian History of England and Wales, vol. II, 1042-1350, Cambridge, 1988, 716-817.

Fossier, R., La terre et les hommes en Picardie jusqu'à la fin du XIIIe siècle, Paris, 1968.

Gemmill, E., and Mayhew, N., Changing Values in Medieval Scotland: A Study of Prices, Money, and Weights and Measures, Cambridge, 1995.

Harvey, P.D.A., "The English inflation of 1180-1220", Past \& Present 61 (1973), 3-30.

Hatcher, J., "Unreal wages: long-run living standards and the 'golden age' of the fifteenth century", in R. Soeiro de Brito, B. Dodd, and C.D. Liddy (eds.), Commercial Activity, Markets and Entrepreneurs in the Middle Ages: Essays in Honour of Richard Britnell, Woodbridge, 2011, 1-24.

Hill, G.F., "The thirty pieces of silver", Archaeologia 59 (1905), 235-54.

Hook, D., "The legend of the thirty pieces of silver", in I. MacPherson and R.J. Penny (eds.), The Medieval Mind: Hispanic Studies in Honour of Alan Deyermond, Woodbridge, 1997, 205-21.

Johnson, W., "Textual sources for the study of Jewish currency crimes in thirteenthcentury England", British Numismatic Journal 66 (1996), 21-32.

Jones, A.H.M., The Later Roman Empire, 284-602: A Social, Economic and Administrative Survey, 4 vols., Oxford, 1964.

Keane, W., "Market, materiality and moral metalanguage", Anthropological Theory 8 (2008), 27-42.

Kelleher, R., and Leins, I., "Roman, medieval and later coins from the Vintry, City of London", Numismatic Chronicle 168 (2008), 167-240.

Kluge, B., Deutsche Münzgeschichte von der späten Karolingerzeit bis zum Ende der Salier (ca. goo bis 1125), Sigmaringen, 1991.

Kotel'nikova, L.A., "Rendita in natura e rendita in denaro nell'Italia medievale (secoli IX-XV)", in R. Romano and U. Tucci (eds.), Storia d'Italia: Annali VI. Economia natural, economia monetaria, Turin, 1983, 93-112. 
Latimer, P., "The English inflation of 1180-1220 reconsidered", Past \& Present 171 (2001), 3-29.

Le Goff, J., Money and the Middle Ages: An Essay in Historical Anthropology, J. Birrell (trans.), Cambridge, 2012.

Ligt, L. de, "Demand, supply, distribution: the Roman peasantry between town and countryside: rural monetization and peasant demand", Münstersche Beiträge zur antiken Handelsgeschichte 9 (1990), 24-56.

Marx, K., Economic and Philosophical Manuscripts of 1844, M. Milligan (trans.), Moscow, 1959 .

Mate, M., "Monetary policies in England, 1272-1307", British Numismatic Journal 41 (1972), 34-79.

Maurer, B., "The anthropology of money", Annual Review of Anthropology 35 (2006), 1536.

Mauss, M., The Gift: The Form and Reason for Exchange in Archaic Societies, W.D. Halls (trans.), M. Douglas (foreword), London, 1990.

Mayhew, N., "Modelling medieval monetisation", in R.H. Britnell and B.M.S. Campbell (eds.), A Commercialising Economy: England 1086 to c.13oo, Manchester, 1995, 55-77.

Mayhew, N., "The monetary background to the Yorkist Recoinage of 1464-1471", British Numismatic Journal 44 (1974), 62-83.

Mell, J., The Myth of the Medieval Jewish Moneylender, 2 vols., London, 2017.

Miller, W.I., Eye for an Eye, Cambridge, 2006.

Morrisson, C., "La devaluation de la monnaie byzantine au XIe siècle: essai d'interprétation", Travaux et mémoires du Centre de Recherche d'Histoire et Civilisation de Byzance 6 (1976), 3-48.

Mundill, R.R., The King's Jews: Money, Massacre and Exodus in Medieval England, London, 2010 .

Munro, J.H., "Deflation and the petty coinage problem in the late-medieval economy: the case of Flanders, 1334-1484", Explorations in Economic History 25 (1988), $387-423$.

Murray, A.V., "Money and logistics in the forces of the First Crusade: coinage, bullion, service, and supply 1096-99", in J.H. Pryor (ed.), Logistics of Warfare in the Age of the Crusades, Aldershot, 2006, 229-50.

Naismith, R., "The Forum hoard and beyond: money, gift, and religion in the early Middle Ages", Viator 47 (2016), 35-56.

Naismith, R., "Gold coinage and its use in the post-Roman West", Speculum 89 (2014), 273-306.

Naismith, R., Money and Power in Anglo-Saxon England: The Southern English Kingdoms 757-865, Cambridge, 2012.

Naismith, R., "The social significance of monetization in the early Middle Ages", Past \& Present 223 (2014), 3-39. 
Naismith, R., "Turpe lucrum? Wealth, money and coinage in the millennial Church", in G.E.M. Gasper and S.H. Gullbekk (eds.), Money and the Church in Medieval Europe, 1000-1200: Practice, Morality and Thought, Farnham, 2015, 17-37.

Naismith,R., and Tinti, F., The Forum Hoard of Anglo-Saxon Coins/Il ripostiglio dell'Atrium Vestae nel Foro Romano (Bollettino di numismatica, 55-56), Rome, 2016.

Oliver, L., The Body Legal in Barbarian Law, Toronto, 2011.

Petry, K., "Die Geldzinse im Prümer Urbar von 893. Bemerkungen zum spätkarolingischen Geldumlauf des Rhein-Maas und Moselraumes im 9. Jahrhundert", Rheinische Vierteljahrblätter $5^{2}$ (1988), 16-42.

Phelps Brown, H., and Hopkins, S.V., A Perspective on Wages and Prices, London, 1981.

Prestwich, M.C., "Edward I's monetary policies and their consequences", Economic History Review, 2nd ser., 22 (1969), 406-16.

Prigent, V., "Le mythe du mancus et les origines de l'économie européenne", Revue numismatique 171 (2014), 701-28.

Reuter, T., "Gifts and simony", in E. Cohen and M. de Jong (eds.), Medieval Transformations: Texts, Power and Gifts in Context, Leiden, 2000, 157-68.

Rigold, S., "Small change in the light of medieval site-finds", in N.J. Mayhew (ed.), Edwardian Monetary Affairs (1279-1344): A Symposium Held in Oxford, August 1976, Oxford, 1977, 59-8o.

Rokéah Z.E., "Money and the hangman in late-13th-century England: Jews, Christians and coinage offences alleged and real", Jewish Historical Studies 31 (1988-90), 83-109.

Sargent, T.J., and Velde, F.R., The Big Problem of Small Change, Princeton, 2002.

Simmel, G., The Philosophy of Money, T. Bottomore, D. Frisby and K. Mengelberg (trans.), Boston, 1978.

Sloane, B., The Black Death in London, Stroud, 2011.

Spufford, P., Handbook of Medieval Exchange, London, 1986.

Spufford, P., Money and Its Use in Medieval Europe, Cambridge, 1988.

Spufford, P., Power and Profit: The Merchant in Medieval Europe, London, 2002.

Stoess, C., "Die Münzen”, in E. Wamers (ed.), Die frühmittelalterlichen Lesefunde aus der Löhrstrasse (Baustelle Hilton II) in Mainz, Mainz, 1994, 177-89.

Todeschini, G., "The incivility of Judas: 'manifest' usury as a metaphor for the 'infamy of fact' (infamia facti)", in J.M. Vitullo and D.B. Wolfthal (eds.), Money, Morality, and Culture in Late Medieval and Early Modern Europe, Farnham, 33-52.

Todeschini, G., "Money and religion", in R. Naismith (ed.), A Cultural History of Money: The Middle Ages, London, forthcoming.

Watson, A.M., "Back to gold and silver", Economic History Review 20 (1967), 1-34.

Wickham, C., Framing the Early Middle Ages: Europe and the Mediterranean, 400-80o, Oxford, 2005 .

Wickham, C., The Mountains and the City: The Tuscan Apennines in the Early Middle Ages, Oxford, 1988. 
Wickham, C., "Rethinking the structure of the early medieval economy", in J.R. Davis and M. McCormick (eds.), The Long Morning of Early Medieval Europe: New Directions in Early Medieval Studies, Aldershot, 2008, 19-31.

Wood, D., Medieval Economic Thought, Cambridge, 2002.

Zelizer, V., The Social Meaning of Money, New York, 1994.

Websites, Etc.

NUMIS: Numismatic Information System (https://nnc.dnb.nl/dnb-nnc-ontsluitingfrontend/\#/numis/).

PAs: Portable Antiquities Scheme (http://www.finds.org.uk). 